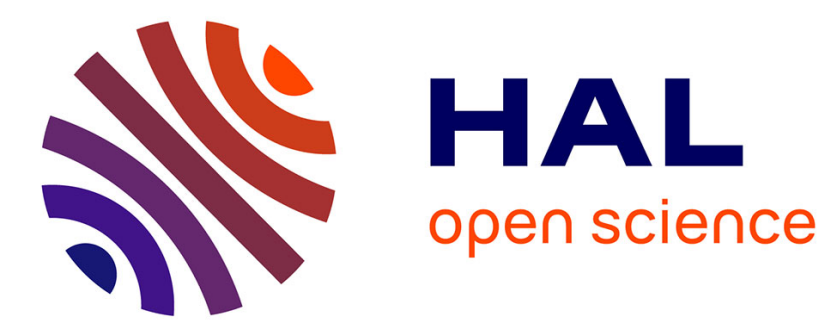

\title{
Leaching of polyphenols from apple parenchyma tissue as influenced by thermal treatments
}

\author{
Mouhamadou Kebe, Catherine M.G.C. Renard, Mohamed El Maataoui, \\ G.N.G. Amani, Jean Francois Maingonnat
}

\section{- To cite this version:}

Mouhamadou Kebe, Catherine M.G.C. Renard, Mohamed El Maataoui, G.N.G. Amani, Jean Francois Maingonnat. Leaching of polyphenols from apple parenchyma tissue as influenced by thermal treatments. Journal of Food Engineering, 2015, 166, pp.237-246. 10.1016/j.foodeng.2015.05.037 . hal-02629836

\section{HAL Id: hal-02629836 \\ https://hal.inrae.fr/hal-02629836}

Submitted on 27 May 2020

HAL is a multi-disciplinary open access archive for the deposit and dissemination of scientific research documents, whether they are published or not. The documents may come from teaching and research institutions in France or abroad, or from public or private research centers.
L'archive ouverte pluridisciplinaire HAL, est destinée au dépôt et à la diffusion de documents scientifiques de niveau recherche, publiés ou non, émanant des établissements d'enseignement et de recherche français ou étrangers, des laboratoires publics ou privés. 


\title{
Leaching of polyphenols from apple parenchyma tissue as influenced by thermal treatments
}

\author{
M. Kebe ${ }^{\mathrm{a}, \mathrm{b}, \mathrm{d}}$, C.M.C.G. Renard ${ }^{\mathrm{a}, *}$, M. El Maâtaoui ${ }^{\mathrm{c}}$, G.N.G. Amani ${ }^{\mathrm{d}}$, J.-F. Maingonnat ${ }^{\mathrm{a}}$ \\ a INRA, UMR 408 Sécurité Qualité des Produits d'Origine Végétale, 84000 Avignon, France \\ ${ }^{\mathrm{b}}$ Avignon Université, UMR 408 Sécurité Qualité des Produits d'Origine Végétale, 8400 Avignon, France \\ ' Avignon Université, Laboratoire de Physiologie des Fruits et Légumes, 8400 Avignon, France \\ ${ }^{\mathrm{d}}$ Nagui Abrogoua Université, UFR Sciences et technologies des aliments, 05 Abidjan, Cote d'Ivoire
}

Keywords:

Apparent diffusivity

Procyanidins

Malus domestica Borkh.

Histology

Texture

\begin{abstract}
A B S T R A C T
Raw, heated and frozen-thawed apple parenchyma of the 'Golden Delicious' and 'Granny Smith' varieties were subjected to leaching and phenolic compounds were analysed by high performance liquid chromatography (HPLC). Fick's second law was applied for the determination of the apparent diffusivity $\left(D_{e}\right)$ of individual polyphenols. Further information was obtained histochemically by means of toluidine blue $O$ staining and image analysis.

No difference in phenolic quantification existed between the biochemical and histochemical approaches. The histochemical analysis revealed cell structure changes and the interaction of procyanidins with the cell wall during the leaching process.

The $D_{e}$ values of the total polyphenols were 0.30 and $0.26 \times 10^{-9} \mathrm{~m}^{2} \mathrm{~s}^{-1}$ for the 'Golden Delicious' and 'Granny Smith' raw apple matrix, respectively. The $D_{e}$ values (and leaching yields) increased after treatments that degraded the plant tissue matrix. After freeze-thaw, the $D_{e}$ values became 0.39 and $0.40 \times 10^{-9} \mathrm{~m}^{2} \mathrm{~s}^{-1}$, while after heating they were 0.92 and $0.38 \times 10^{-9} \mathrm{~m}^{2} \mathrm{~s}^{-1}$. There was also an influence of the phenolic compound nature.
\end{abstract}

\section{Introduction}

Polyphenols are phytochemical compounds that are present in almost all fruits and vegetables (Macheix et al., 2003). Epidemiological studies have linked their consumption to a reduced risk of cancer (Ader et al., 1996) and cardiovascular diseases (Bernards and Lewis, 1998). A reduction in the risk of lung cancer, asthma, type-2 diabetes, thrombotic stroke, ischemic heart disease, and proliferation activities have been attributed to apple consumption (Boyer and Liu, 2004; Wu et al., 2004).

The apple (Malus domestica Borkh.), is the main food source of polyphenols in western countries (Boyer and Liu, 2004) because

Abbreviations: Maxl, force representing the limit of flesh elasticity; WkMaxl, work to attain the limit of flesh elasticity; $L L$, force detected at the end of penetration; $W k L$, work required to attain a flesh deformation; DM loss, dry matter loss during soaking; $\mathrm{DM}_{40}$, dry matter from parenchyma heated at $40{ }^{\circ} \mathrm{C} ; \mathrm{DM}_{70}$, dry matter from parenchyma heated at $70^{\circ} \mathrm{C} ; \mathrm{DM}_{-25}$, dry matter from parenchyma frozen at $-25^{\circ} \mathrm{C}$

* Corresponding author at: UMR 408 SQPOV, INRA, Domaine St Paul, CS40509, 84914 Avignon cedex 09, France.

E-mail address: catherine.renard@avignon.inra.fr (C.M.C.G. Renard). it is available for the entire year, making it a major source of dietary antioxidants. Generally, three classes of phenolic compounds are present in the parenchyma of apple fruit: hydroxycinnamic acids (primarily caffeoylquinic acid varying from 35 to $178 \mathrm{mg} / \mathrm{kg}$ ), monomeric and oligomeric flavan-3-ols (procyanidins varying from 378 to $753 \mathrm{mg} / \mathrm{kg}$ ), and dihydrochalcones (phloridzin varying from 13 to $91 \mathrm{mg} / \mathrm{kg}$ ) (Guyot and Drilleau, 2002; Guyot et al., 1998; Vrhovsek et al., 2004). Flavonols and anthocyans are generally found only in apple skin.

The phenolic profile varies with the genetic variation, most importantly as well as the growth period, growing season, and geographical location. In addition, different histochemical method have been developed on fruit tissue to locate various polyphenols such as procyanidins by light microscopy (Cadot et al., 2011).

Fruit processing modifies their biochemical and mechanical properties (Van Buggenhout et al., 2009). Most treatments thus cause an initial loss of instrumental firmness due to the disruption of tissue and cell structures. Therefore, they allow the free diffusion of water and low-molecular weight moieties with loss of turgor (Greve et al., 1994). Further texture loss is linked to cell walls degradation, which might also lead to easier solute movement 
throughout the tissue by increasing pore sizes in the cell walls (Waldron et al., 1997). Blanching, osmotic dehydration (OD), drying or vacuum impregnation are well-known processing operations for which the mass transfer has been studied by several authors (Devic et al., 2010a; Rice et al., 1990; Sineiro et al., 1996).

The mass transfer study of the movement of solutes in a medium, consists of two main phenomena:

- Extraction where a solute is extracted from a solid to a medium. Extractions of oils from plants, sugar from sugar beets, and apple juice are common examples.

- Infusion consists of the entrance of a solute into a solid. Some molecules of interest are infused into foodstuff to enhance their nutritional quality or shelf life e.g. preservation by salting or acidification where acids diffuse from the solution into the food (Scharwtzberg and Chao, 1982). Infusion of health-benefitting molecules could also enhance their nutritional value (Klewicki and Uczciwek, 2008).

Many studies have considered solutes diffusion in different processing conditions for fruit and vegetables. The phenomena are usually time dependent and are better represented by Fick's second law for unsteady state diffusion (Varzakas et al., 2005). However, mass transfer mechanisms are difficult to clarify because of the complex morphology of plant tissue (Keurentjes et al., 1992).

Very few studies have been carried out to determine on polyphenol behaviour in function of raw and treated fruit tissue.

Renard (2005) reported on partial leaching of hydroxycinnamic acid and important flavan-3-ols retention in pear parenchyma during heating. Furthermore, polyphenol losses increased with $1 \mathrm{~h}$ of heating time with $65 \%$ of the original flavan-3-ols and $40 \%$ of the original caffeoylquinic acid retained in pear tissues. Texture changes with cell destructuration (Bourles et al., 2009; Chassagne-Berces et al., 2009) are expected to influence phenolic compounds diffusion. Structure, the main contributing factor to textural properties of fruit includes cellular turgor and cell wall integrity, both of which are lost during heat treatment (De Belie, 2002); cellular turgor requires membrane integrity, and its loss is a sign of the loss of cellular compartmentalization, while cell wall degradation leads to larger pore sizes and hence also facilitates diffusion (Waldron et al., 1997).

The purpose of this paper is (i) to follow phenolic compounds changes in raw apple parenchyma during soaking and (ii) to analyse the influence of parenchyma thermal degradation. Histochemical analysis was performed for comparison with biochemical results to better understand the mechanisms involved.

\section{Materials and methods}

\subsection{Plant materials}

Apples were purchased at a local supermarket (Auchan, Avignon); the varieties chosen were 'Golden Delicious' and 'Granny Smith'. The two dessert apple varieties were selected for their different phenolic content. Apples were selected on the basis of their visual uniformity and absence of damages or blemishes. Fruit pieces were stored at $4{ }^{\circ} \mathrm{C}$ before each experiment and were brought up to room temperature $24 \mathrm{~h}$ before analysis.

Peeled apples were cut into slices that were $2 \mathrm{~cm}$ thick in the transverse direction at the equatorial region.

To prevent any polyphenol oxidation, apple slices were sprayed with a solution of $40 \mathrm{~g} / \mathrm{L}$ sodium fluoride $(\mathrm{NaF})$, a potent inhibitor of polyphenoloxidase (Fujita and Tono, 1988). A total of 10 fruits per cultivar were used in a soaking experiment that was replicated two or three times. Samples were subjected to thermal treatments before the leaching process.

\subsection{Thermal processing}

\subsubsection{Freezing and thawing}

The treatments consisted of freezing apple samples at $-25^{\circ} \mathrm{C}$ for $1 \mathrm{~h}$. Once frozen, the samples were packed into polyethylene bags and thawed in a cold chamber at $4{ }^{\circ} \mathrm{C}$ overnight. They were equilibrated at room temperature for $2 \mathrm{~h}$ before each experiment.

\subsubsection{Heating and cooling}

After being hermetically sealed in a polyethylene bag with a vacuum machine (Multivac-A300/16-3987), the apple slices were immediately immersed in hot water. Heating was carried out at a constant temperature. The temperatures tested were $40^{\circ} \mathrm{C}$ and $70{ }^{\circ} \mathrm{C}$. Indeed, at $40^{\circ} \mathrm{C}$, the cell walls are intact with protein transporters, but at $70^{\circ} \mathrm{C}$, the heating induced destructuration of cell membranes. For each treatment temperature, the process times were varied from 0 to $30 \mathrm{~min}$. The apples slices were cooled in an ice water for $5 \mathrm{~min}$ to halt the heating.

\subsection{Mechanical properties}

Penetrometry tests were performed with a TA.XT2 texture analyser (Stable Systems Ltd., Godalming, UK) as described by Chassagne-Berces et al. (2009) and Mehinagic et al. (2003), with a $2 \mathrm{~mm}$ diameter cylindrical probe, penetrating $10 \mathrm{~mm}$ deep into samples at $100 \mathrm{~mm} / \mathrm{min}$. A force vs. deformation curve was obtained (Fig. 1). Penetrometry curves were analysed and four parameters were derived as follows: (1) the load at flesh limit of compression (Maxl), (2) the load at the limit $(L L),(3)$ the work of the load at the limit ( $W k L)$ and (4) the work of the load at the flesh limit compression ( WkMaxl). Three measurements were performed on the raw and processed apple slices.

\subsection{Mass transfer of samples}

\subsubsection{Experiment}

Raw and treated slices were immersed in a water bath at room temperature and stirred by a magnetic stirrer. Leaching was performed at a solid to liquid ratio of 1:30. To prevent any polyphenol oxidation, $\mathrm{NaF}$ at $5 \mathrm{~g} / \mathrm{L}$ was also added to the distilled water. After

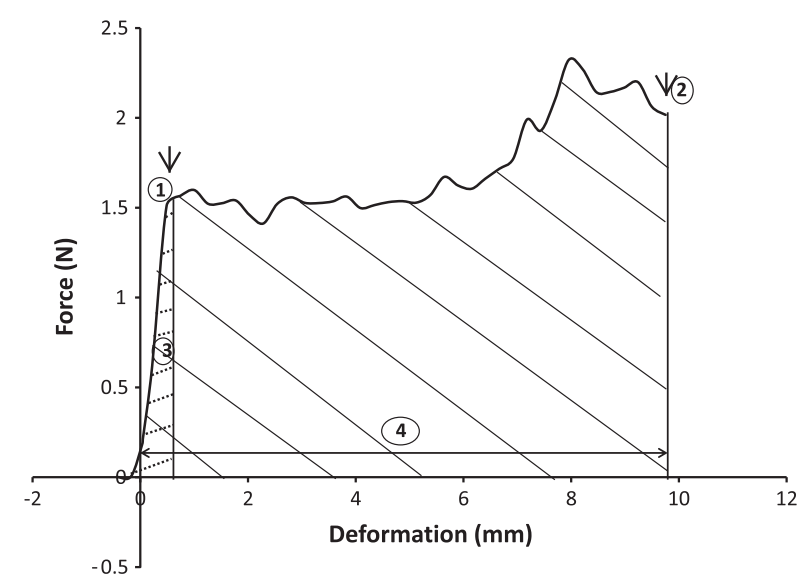

Fig. 1. Typical force and deformation curve on for a raw peeled apple using a TAXT2 (Stable Systems Ltd., Godalming, UK) traction machine $\left(100 \mathrm{~mm} \mathrm{~min}^{-1}\right.$, depth of $10 \mathrm{~mm}$ ). Four texture parameters are identified: (1) Maxl: load at the flesh limit of compression, (2) WkMaxl: work of the load at the flesh limit, (3) $L L$ : load at the end of penetration, (4) WkLL: work of the load at the end of penetration. 
different soaking durations, apple slices were taken out of the water, left to drip for a few minutes and gently blotted with tissue paper, then frozen and freeze-dried in a lyophilizer (Usifroid, France) for $48 \mathrm{~h}$ or $72 \mathrm{~h}$. A homogenous powder was obtained by crushing the dried tissues with a closed laboratory mill to avoid hydration. The powders were stored in desiccators.

Matrix mass changes were measured to determine the water gain, after each immersion time during the leaching experiments. The measurements were repeated three times. Changes were determined using Eq. (1):

$\% W_{g}=\frac{M_{(t)}-M_{o}}{M_{o}} \times 100$

with $W_{g}$ : Water gain percentage,

$M_{o}$ : Matrix weight $(\mathrm{g})$ before the experiment,

$M_{(t)}$ : Matrix weight $(\mathrm{g})$ during the experiment at time $t$.

\subsubsection{Theoretical considerations}

When modelling diffusion phenomena related to food processing, the concentration gradient is usually time dependent and diffusion may be better represented by Fick's second law for unsteady state diffusion (Varzakas et al., 2005), shown in Eq. (2).

$\frac{\partial C(x, t)}{\partial x}=D_{e} \frac{\partial^{2} C(x, t)}{\partial x^{2}}$

where $C$ represents the concentration at a given point of coordinate $x$ at time $t$ during unidirectional mass transfer.

$D_{e}\left(\mathrm{~m}^{2} \mathrm{~s}^{-1}\right)$, the apparent diffusivity can be used to characterize the diffusive process, in particular, to determine the effect of solvent viscosity and temperature which are often the most variable (Varzakas et al., 2005).

To solve Eq. (2), the following boundary conditions were set: $x= \pm a ; C=C_{0}$ and $-a<x<a, C=f(t)$ with a sample thickness of $2 a$.

When using apple slices, the geometry can be considered that of a slab, i.e., a "thin film with negligible edge effects". Diffusional mass transport through the edges of the film is negligible compared to diffusional mass transport through the film's main surface.

The solution proposed by Crank (1975) for slab diffusion is as follows (Eq. (3)):

$$
\frac{C_{(t)}-C_{\infty}}{C_{o}-C_{\infty}}=\frac{8}{\pi^{2}} \sum_{n=1}^{n \rightarrow \infty} \frac{1}{(2 n+1)^{2}} \exp \left(\frac{D_{e}(2 n+1)^{2}}{4 a^{2}} \pi^{2} t\right)
$$

The Equation can be reduced to the following (Eq. (4)) (Benhamou et al., 2008):

$\frac{C_{(t)}-C_{\infty}}{C_{o}-C_{\infty}}=\frac{8}{\pi^{2}} \exp \left(-\frac{D_{e}}{4 a^{2}} \pi^{2} t\right)$

$C=$ average solute concentration in the apple slice at time $t$ of sampling; $C_{o}=$ initial uniform concentration in the disk; $C_{\infty}=$ solute concentration in apple slices at equilibrium after a long processing time.

We applied Eq. (4) to each set of conditions tested, and the adjustable parameters for sugar and polyphenol decreases were determined.

\subsection{Biochemical analysis}

Biochemical analyses were performed on product reduced to powder after freeze-drying.

\subsubsection{Solvents and chemicals}

Methanol, acetonitrile, and acetone of HPLC grade were purchased from Fisher Scientific (Fair Lawn, NJ, USA), and toluene- $\alpha$-thiol was provided by Sigma-Aldrich (Deisenhofen, Germany). Deionized water was obtained with a Milli-Q water system (Millipore, Bedford, MA). (+)-Catechin, (-)-epicatechin, caffeoylquinic acid, mannitol, glucose and fructose were also provided by Sigma-Aldrich (Deisenhofen, Germany). Phloretin and $p$-coumaroylquinic acid were obtained from Extrasynthese (Lyon, France). Phloridzin was obtained from Fluka (Buchs, Switzerland).

\subsubsection{Quantification of sugar}

Fruit parenchyma freeze-dried powder ( $5 \mathrm{~g}$ ) was suspended in $20 \mathrm{~mL}$ of distilled water and homogenized with a polytron homogenizer for $1 \mathrm{~min}$. The homogenates were centrifuged at $9000 \mathrm{~g}$ for $10 \mathrm{~min}$ at $4{ }^{\circ} \mathrm{C}$. The supernatant was collected to analyse sugars by the colorimetric enzymatic method as described in Bureau et al. (2012).

\subsubsection{Quantification of polyphenols by HPLC after thioacidolysis}

Polyphenols were quantified by HPLC after thioacidolysis as described by Bureau et al. (2012). The average degree of polymerisation $\left(D P_{n}\right)$ was calculated as the molar ratio of all of the flavan-3-ol units (thioether adduct plus terminal unit) to (-)-epicatechin and (+)-catechin corresponding to the terminal units. An HPLC system equipped with a diode array detector (SPD-M20A Shimadzu Inc., Kyoto, Japan) and a Column LichroCART $250 \times 4 \mathrm{~mm}$, LiChrospher $100 \mathrm{RP}-18(5 \mu \mathrm{m})$ were used. Quantification was performed using external standards. The results are expressed in milligram per kilogram fresh weight (FW). Losses of phenolic compounds ( $M C$ ) were calculated, using Eq. (5):

$$
\begin{aligned}
& \% \mathrm{MC}=\frac{\mathrm{DM}_{(0)} \cdot C_{(0)}-\mathrm{DM}_{(t)} \cdot C_{(t)}}{\mathrm{DM}_{(0)} \cdot C_{(0)}} \times 100 \\
& \text { DM Losses }=\mathrm{DM}_{(0)}-\mathrm{DM}_{(15 \mathrm{~h})} \\
& \% \text { Ret. }=\frac{C_{(0)}-C_{(\infty)}}{C_{(0)}}
\end{aligned}
$$

with $C_{(0)}=$ initial phenolic compound concentration in the sample ( $\mathrm{mg} / \mathrm{kg}$ Dry Weight),

$C_{(t)}=$ phenolic compound concentration in the sample at time $t$ (mg/kg Dry Weight),

$\mathrm{DM}_{(0)}=$ initial dry matter of the sample (g/100 g FW),

$\mathrm{DM}_{(t)}=$ dry matter of the sample at time $t(\mathrm{~g} / 100 \mathrm{~g} \mathrm{FW})$.

Values are expressed as a percent $(w / w)$ of the initial compound concentration.

\subsection{Light microscopy visualization}

To visualize procyanidins in light microscopy the HAEM procedure described by Brillouet and Escoute (2012) was used. This procedure is based on the stabilization of procyanidins by hemoglobin during the fixation step. Apple tissue pieces (approximately $0.5 \mathrm{~mm}^{3}$ ) were collected from each treatment and immediately immersed in a fixative solution containing $20 \mathrm{~g} / \mathrm{L}$ glutaraldehyde (Sigma-Aldrich) and, $10 \mathrm{~g} / \mathrm{L}$ acrolein (Sigma-Aldrich) in phosphate-buffered saline (PBS). After $20 \mathrm{~h}$ fixation at $4{ }^{\circ} \mathrm{C}$, specimens were rinsed in PBS and successively treated with glycine ( $0.1 \mathrm{M}$ for $10 \mathrm{~min}$ ) and bovine hemoglobin (Sigma-Aldrich) $(70 \mathrm{~g} / \mathrm{L}$ in PBS). Specimens were then rinsed, dehydrated and embedded in historesin (Technovit 7100; HeraeusKulzer GmbH, Bad Wehrheim, Germany) based on the work of Brillouet and Escoute (2012). Microtome sections ( $3 \mu \mathrm{m}$ thick) were stained by toluidine blue $\mathrm{O}$ (TBO). Observations and photographs were made using a Leica DM 2000 photomicroscope (Leica Instruments, Nussloch, Germany) equipped for bright field and UV 
illuminations. Images were captured using a Leica DFC 300 FX digital camera (Leica) and analysed with LAS software (Leica). Approximately 5 tissue fragments were examined for each treatment.

\subsection{Statistical analysis}

SPSS (Version 7) software was used for statistical analysis. The data were subjected to statistical analysis using the analysis of variance (ANOVA) test. Means were compared using Duncan's multiple range tests. A non linear regression analysis module was also used to determine apple matrix content characteristics and their response to the leaching process. To obtain the parameters of the models, the non linear regression tool in the R statistical software was used.

\section{Results and discussion}

\subsection{Effects of thermal processing on apple texture}

Four texture parameters were recorded during penetrometric tests. Their analyses showed correlation coefficients $>90 \%$, and therefore, only "Maxl", is reported as the main parameter. Apples texture decreased after thermal treatments (Fig. 2). Indeed, flesh firmness decreased by $60 \%$ for 'Golden Delicious' and $20 \%$ for 'Granny Smith' after $30 \mathrm{~min}$ at $70^{\circ} \mathrm{C}$. No significant texture loss was observed for both apple varieties at $40^{\circ} \mathrm{C}$. Similar results were reported in the literature (Billy et al., 2008; Bourles et al., 2009).

Heating at $70^{\circ} \mathrm{C}$ likely induced microstructural changes at the cellular level: cells membrane disintegration, cell wall break-down or a decrease in cell-to-cell adhesion. However these microstructural changes appear to differ little with apple variety.

The loss of texture of frozen-thawed apple slices was 30\% and $85 \%$ of the initial firmness of raw 'Granny Smith' and 'Golden Delicious' specimens, respectively. Similar results were reported in the literature (Billy et al., 2008; Bourles et al., 2009; Chassagne-Berces et al., 2009; Mehinagic et al., 2003). For freeze-thaw, the texture loss is linked to cell membrane ruptures inducing cytolysis: Chassagne-Berces et al. (2009) reported no intact cell vacuoles in frozen-thawed apple parenchyma tissue.

\subsection{Effects of processing on water intake and the leaching of dry matter (DM)}

Fig. 3 reveals water intake during soaking. A water gain (estimated from the weight gain) of $8 \%$ ('Golden Delicious') and $14 \%$

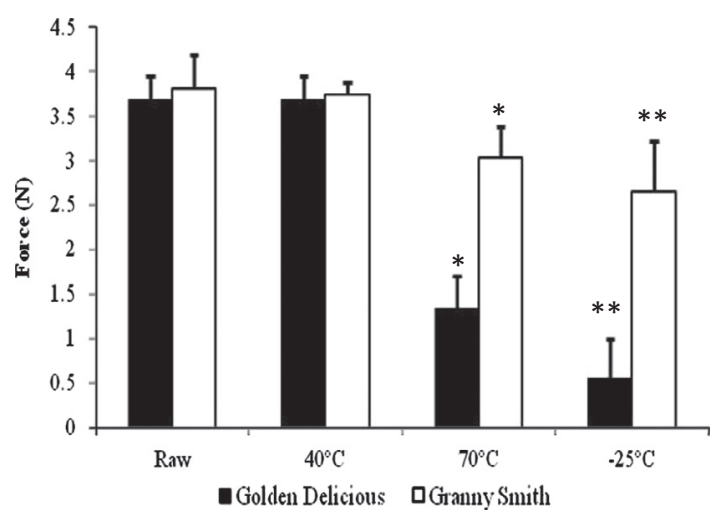

Fig. 2. Texture changes of raw and treated $\left(40^{\circ} \mathrm{C}, 70^{\circ} \mathrm{C}\right.$ and $-25^{\circ} \mathrm{C} / 30 \mathrm{~min}$ ) parenchyma of apple varieties ( $\square$ 'Golden Delicious' and $\mathbf{\square}$ 'Granny Smith'). Three biological replicates were performed. Asterisks on bars $\left({ }^{* * *}\right)$ indicate that the results are significantly different (Duncan's post hoc test, $p<0.05$ ).
('Granny Smith') in raw parenchyma was observed after $15 \mathrm{~h}$. With treated parenchyma, similar water gains were obtained for 'Golden Delicious' apples with increases of 9-15\%, however the impact was more heterogeneous for 'Granny Smith' apples, with even a weight decrease for frozen-thawed specimens. Most of the weight changes occured during the first $3 \mathrm{~h}$, followed by a plateau, except for raw 'Granny Smith' apples.

Simultaneous to this limited water gain, there was a major decrease in dry matter content in the apple slices, much larger than the dilution effect linked to water intake, signalling actual dry matter loss via leaching to the outer water. Dry matter from raw parenchyma $\left(\mathrm{DM}_{i}\right)$ represented $13.71( \pm 0.19)$ and 12.70 $( \pm 0.20) \mathrm{g} / 100 \mathrm{~g}$ FW for 'Granny Smith' and 'Golden Delicious', respectively. Apple parenchyma had high moisture content, as expected (Bourles et al., 2009; Campeanu et al., 2009; Keurentjes et al., 1992). Fig. 3 presents changes for both apple varieties for raw $\left(\mathrm{DM}_{i}\right)$ and treated parenchyma $\left(\mathrm{DM}_{40}, \mathrm{DM}_{70}, \mathrm{DM}_{-25}\right)$ during soaking as a function of time. After $15 \mathrm{~h}$, for both apple varieties DM losses in raw parenchyma, (Eq. (6)) reached 35\% and 50\%. The amount of losses increased for all treated parenchyma over time, eventually reaching $50-60 \%$ of DM measured. Thermal treatments (either heating or freeze-thaw) thus increase DM losses by leaching. This was likely linked to induced cell destructuration (loss of cell compartmentalization) and cell wall degradation. Two phenomena might explain this loss of cell integrity in the raw apple samples, either cell fracture by cutting during sample preparation, or membrane explosion through osmotic pressure differential. The removal of the apple epidermis and the cutting into slices could cause the rupture of the tonoplast of the cells at the fracture surfaces, exposing the internal nutrients to the outer solution and causing their release into the water. However quantitatively this could only account for a limited part of the sugar release; assuming an average cell diameter of $100 \mu \mathrm{m}$, as determined by Chassagne-Berces et al. (2009), and a slice height fixed at $2 \mathrm{~cm}$, the outer cell layer accounts for at most up to $10 \%$ of the tissue volume. Most sugar content in the dry matter loss was therefore probably due to cytolysis-plasmoptysis as observed in Kebe et al. (2014).

Two simultaneous phenomena thus took place during parenchyma soaking, water intake and solute loss. As raw parenchyma presents high osmotic potential, and the leaching was carried out in pure water, there is a strong imbalance between the inner and outer mediums. Such imbalances could cause water entrance and therefore volume changes and cytolysis, up to cell wall rupture (Scharwtzberg and Chao, 1982). In Kebe et al. (2014), we compared the behaviour of 'Golden Delicious' and 'Granny Smith' apples in mannitol solutions of different molarities. The samples length increased up to $0.4 \mathrm{M}$, and the turgor pressure found was $-1.15 \mathrm{MPa}$ (equilibrium mannitol molarity at $0.43 \mathrm{M}$ ) for 'Granny Smith' and $-1.49 \mathrm{MPa}$ (equilibrium at $0.61 \mathrm{M}$ ) for 'Golden Delicious', with significant dry matter losses only when the difference in molarity between the equilibrium point and the solution was >0.2 M. Lin and Pitt (1986) measured high turgor pressure for plant tissues in water and concluded that cell rupture could be caused by cytolysis-plasmoptysis.

For treated (heated or freeze-thawed) parenchyma, diffusion is facilitated by the loss of cell structure and solutes diffuse through the tissue (a porous material), with physico-chemical hindrances due to the cell walls. The limiting factor for solute leaching from apple tissue is likely their migration through the apple tissue, and not their dissolution in the excess water. Apparent diffusivity constants can be calculated to account for the phenomenon. Migration inside this cellularly compartmentalized medium is likely to be far from true diffusion as assumed in Fick's laws, but these equations and their derivations for various sample geometries provide a convenient framework that gives a satisfactory 


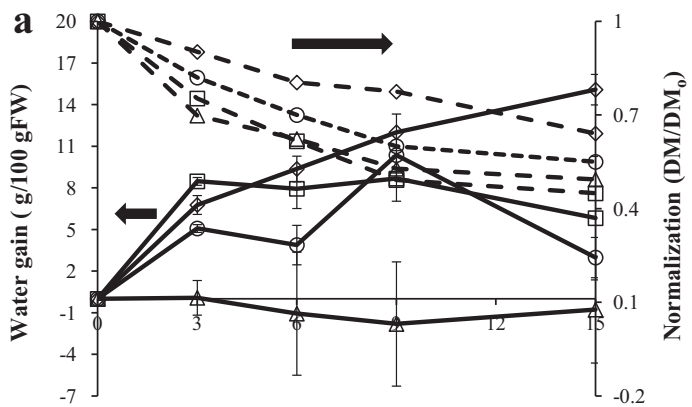

time (h)

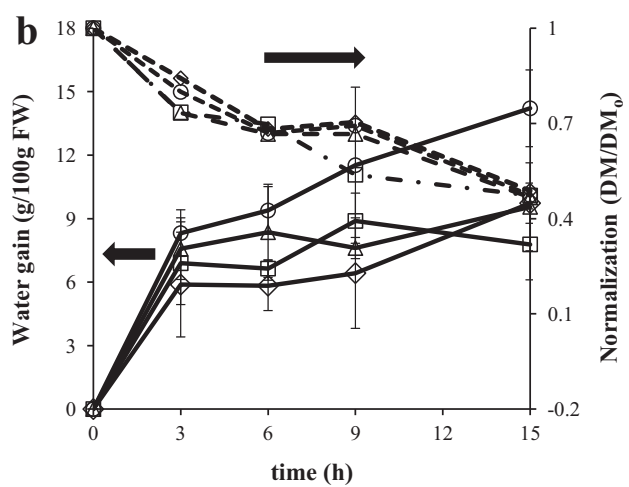

time (h)

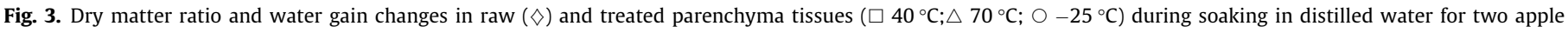
varieties: (b) ‘Golden Delicious', (a) ‘Granny Smith’ (three biological replicates).

quantitative description. Various solutions of Fick's second law have been presented for the diffusion of a compound during solid-liquid extraction, and the one corresponding to a flat slab was applied here (Eq. (4)).

Application of Fick's second law permitted estimation of the DM diffusion coefficients in raw and treated parenchyma (Table 1). The apparent diffusivity values for dry matter, i.e., the global solute diffusion, increased with parenchyma thermal treatments. Similar results were found previously by Delchier et al. (2012).

\subsection{Leaching of sugars}

Fig. 4 shows the sugar changes in raw and treated parenchyma as a function of time. Sugars represent the bulk of apple dry matter (with 9.6 and $10 \mathrm{~g} / 100 \mathrm{~g}$ for 'Granny Smith' and 'Golden Delicious', respectively) and similar behaviours were observed. Sugar contents of both apple varieties decreased during the leaching process. From raw parenchyma, sugar losses plateaued at $30-40 \%$ for both apple varieties. The losses increased for all treated parenchyma samples, both for total loss levels and speed. In Fig. 4, the data were modelled using Crank's (1975) analytical solutions for Fick's second law. The coefficients of diffusion (Table 1) increased from 0.39 to $0.84 \times 10^{-9} \mathrm{~m}^{2} \mathrm{~s}^{-1}$ for 'Golden Delicious' and 0.34 to $0.81 \times 10^{-9} \mathrm{~m}^{2} \mathrm{~s}^{-1}$ for 'Granny Smith', and were not significantly different from those obtained for total dry matter, as expected as sugars constitute most of the apple dry matter. Approximately $60 \%$ of sugars were lost after $15 \mathrm{~h}$ of soaking.

The apparent diffusivity values for total sugar losses were within the range typically reported for 'Golden Delicious' parenchyma under similar conditions (Jemai and Vorobiev, 2002; Leach et al., 1995). Increases of the apparent diffusivity of total sugar were observed after treatment at $70^{\circ} \mathrm{C}$ and after freeze-thaw, i.e., the treatments most likely to impact cell and cell wall integrity. As described for dry matter, a slight loss during soaking was enabled in raw tissues by cytolysis-plasmoptysis. The dry matter loss was thus facilitated after loss of cell integrity by heat treatment at $70^{\circ} \mathrm{C}$ or freeze-thaw.

\subsection{Leaching of polyphenols}

\subsubsection{Initial polyphenol compositions}

The initial measurements of polyphenol compositions are presented in Table 2. Both apple varieties ('Golden Delicious' and 'Granny Smith') main antioxidants are polyphenols. 'Granny Smith' contained more polyphenols than 'Golden Delicious'. The results were similar to those of previous studies (Guyot and Drilleau, 2002; Valavanidis et al., 2009; Vrhovsek et al., 2004).
According to HPLC individual identification, polyphenols from three subclasses were present in the flesh of both apples:

- Flavan-3-ols: monomeric catechins and procyanidins.

- Hydroxycinnamic acids (caffeoylquinic acid, para-coumaroylquinic acid).

- Dihydrochalcones (phloretin xyloglucoside and phloridzin).

In agreement with Guyot and Drilleau (2002) and Sanoner et al. (1999), procyanidins were the main class of phenolic compounds in apple flesh, representing 69\% of total polyphenols in 'Golden Delicious' and 85\% in 'Granny Smith'. Their degrees of polymerization $\left(D P_{n}\right)$ were comparable to those observed by Guyot and Drilleau (2002) or Le Bourvellec et al. (2011). Caffeoylquinic acid, the main hydroxycinnamic acid, accounted for $17.4 \%$ of the total polyphenols in 'Golden Delicious' and less than 6\% in 'Granny Smith', again comparable to Guyot and Drilleau (2002). Finally, dihydrochalcones accounted for less than $2 \%$ of the total polyphenols in both apple varieties, as reported by Devic et al. (2010b) and Oszmianski et al. (2007).

\subsubsection{Polyphenol changes in raw apple parenchyma during soaking}

During soaking, polyphenol concentrations decreased for all classes, with comparable behaviours in both varieties, as shown in Fig. 5 for procyanidins and caffeoylquinic acid, which are the two most abundant polyphenols in apples (for other classes, see supplementary material). In all cases, the losses plateaued between 9 and $15 \mathrm{~h}$ of soaking. High standard deviations were observed, likely due to the variability in the raw materials (Table 2). Lesser losses were observed for procyanidins than for other classes, and complete extraction was not reached.

For 'Granny Smith', the losses of procyanidins were 20\% of the initial concentration and their $D P_{n}$ increased from 6.2 to 6.8 after $15 \mathrm{~h}$ of soaking. Caffeoylquinic acid decreased by $40 \%$, while para-coumaroylquinic acid fell to $50 \%$, close to the losses observed for (-)-epicatechin, or (+)-catechin (40\% and 35\% respectively; see the supplementary material).

Phloretin xyloglucoside and phloridzin decreased by $72 \%$ and $70 \%$, respectively (the graphs are not presented). In the 'Golden Delicious' variety, procyanidins decreased by $30 \%$ and their $D P_{n}$ increased from 6 to 7. Caffeoylquinic acid fell to 74\% but losses of (+)-catechin were $60 \%$ of initial quantity and (-)-epicatechin, $55 \%$. Phloretin xyloglucoside and phloridzin fell to $40 \%$ and $33 \%$, respectively (the graphs are not presented).

In both apples, losses of monomeric catechins, hydroxycinnamic acids and dihydrochalcones were more pronounced than for procyanidins, though less than for sugars. Diffusion of lower molecular weight phenolic compounds was reported by Devic 
Version définitive du manuscrit publiée dans / Final version of the manuscript published in :

Journal of Food Engineering (2015), Vol. 166, p. 237-246, DOI: 10.1016/j.foodeng.2015.05.037

Journal homepage : http://www.elsevier.com/locate/ifoodeng

Table 1

Apparent diffusivity with equilibrium content $\left(C_{\infty} / C_{o}\right)$ for dry matter and sugars leaching from the raw and treated apple slices (three biological replicates).

\begin{tabular}{|c|c|c|c|c|c|c|c|c|}
\hline \multirow[t]{3}{*}{ Thermal treatment } & \multicolumn{4}{|l|}{ 'Granny Smith' } & \multicolumn{4}{|l|}{ ‘Golden Delicious' } \\
\hline & \multicolumn{2}{|l|}{ Dry matter } & \multicolumn{2}{|l|}{ Total sugars } & \multicolumn{2}{|l|}{ Dry matter } & \multicolumn{2}{|l|}{ Total sugars } \\
\hline & $D_{e}\left(10^{-9} \mathrm{~m}^{2} \mathrm{~s}^{-1}\right)$ & $\overline{C_{\infty} / C_{o}}$ & $D_{e}\left(10^{-9} \mathrm{~m}^{2} \mathrm{~s}^{-1}\right)$ & $\overline{C_{\infty} / C_{o}}$ & $D_{e}\left(10^{-9} \mathrm{~m}^{2} \mathrm{~s}^{-1}\right)$ & $\overline{C_{\infty} / C_{o}}$ & $D_{e}\left(10^{-9} \mathrm{~m}^{2} \mathrm{~s}^{-1}\right)$ & $C_{\infty} / C_{o}$ \\
\hline Raw & $0.15 \pm 0.06^{\mathrm{a}}$ & 0.65 & $0.34 \pm 0.05$ & 0.62 & $0.22 \pm 0.10$ & 0.49 & $0.39 \pm 0.12$ & 0.57 \\
\hline $40^{\circ} \mathrm{C}$ & $0.24 \pm 0.09$ & 0.55 & $0.47 \pm 0.08$ & 0.60 & $0.22 \pm 0.10$ & 0.47 & $0.51 \pm 0.12$ & 0.56 \\
\hline $70^{\circ} \mathrm{C}$ & $0.51 \pm 0.06$ & 0.49 & $0.73 \pm 0.09$ & 0.43 & $0.46 \pm 0.14$ & 0.47 & $0.84 \pm 0.12$ & 0.39 \\
\hline Freeze-thawed $\left(-25^{\circ} \mathrm{C}\right)$ & $0.75 \pm 0.11$ & 0.45 & $0.81 \pm 0.07$ & 0.37 & $0.44 \pm 0.21$ & 0.46 & $0.81 \pm 0.07$ & 0.41 \\
\hline
\end{tabular}

a Standard error.
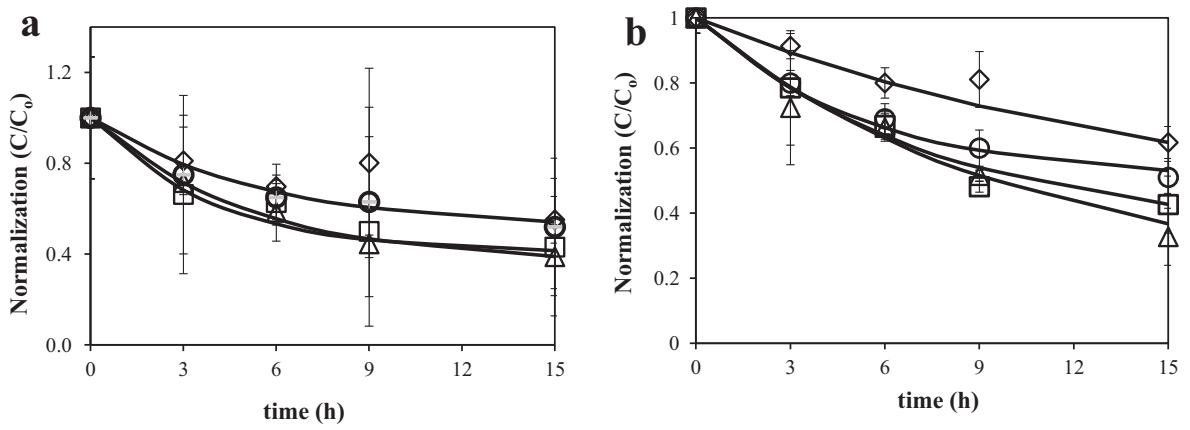

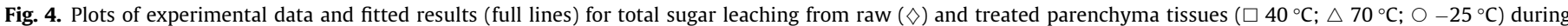
soaking in distilled water for two apple varieties: (a) 'Granny Smith' and (b) 'Golden Delicious' (three biological replicates).

Table 2

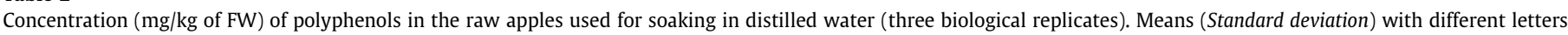
within a row for each phenolic compound are significantly different $(p<0.05)$.

\begin{tabular}{|c|c|c|c|c|c|c|c|c|c|c|}
\hline Variety & Time (h) & CAT & EPI & PCA & DP & CQA & $p C Q$ & XPL & PLZ & PT \\
\hline \multirow[t]{5}{*}{ 'Golden Delicious' } & 0 & $10^{\mathrm{a}}(1)$ & $47^{\mathrm{a}}(3)$ & $339^{\mathrm{a}}(47)$ & $6^{a}(1)$ & $86^{a}(5)$ & $5^{\mathrm{a}}(1)$ & $5^{a}(1)$ & $6^{\mathrm{a}}(1)$ & $509^{a}(63)$ \\
\hline & 3 & $9^{\mathrm{ab}}(1)$ & $42^{\mathrm{ab}}(3)$ & $330^{\mathrm{b}}(47)$ & $6^{a}(1)$ & $75^{\mathrm{a}}(7)$ & $4^{\mathrm{a}}(1)$ & $5^{a}(1)$ & $5^{\mathrm{b}}(1)$ & $481^{\mathrm{ab}}(13)$ \\
\hline & 6 & $7^{\mathrm{bc}}(1)$ & $32^{\mathrm{bc}}(0)$ & $252^{c}(55)$ & $6^{a}(1)$ & $58^{\mathrm{ab}}(1)$ & $4^{a}(1)$ & $3^{c}(1)$ & $6^{\mathrm{a}}(1)$ & $430^{\mathrm{abc}}(48)$ \\
\hline & 9 & $7^{\mathrm{cd}}(1)$ & $28^{c}(7)$ & $326^{\mathrm{bc}}(14)$ & $7^{a}(1)$ & $34^{\mathrm{bc}}(13)$ & n.d & $4^{\mathrm{b}}(1)$ & $6^{a}(1)$ & $370^{\mathrm{bc}}(28)$ \\
\hline & 15 & $4^{\mathrm{cd}}(0)$ & $21^{\mathrm{c}}(5)$ & $262^{\mathrm{C}}(50)$ & $7^{\mathrm{a}}(0)$ & $22^{\mathrm{c}}(10)$ & n.d & $3^{c}(1)$ & $4^{\mathrm{bc}}(1)$ & $332^{\mathrm{c}}(58)$ \\
\hline \% Ret. & & 40 & 45 & 77 & & 26 & n.d & 60 & 67 & 66 \\
\hline \multirow[t]{5}{*}{ 'Granny Smith' } & 0 & $29^{\mathrm{a}}(6)$ & $65^{\mathrm{a}}(8)$ & $900^{\mathrm{a}}(34)$ & $6^{a}(0)$ & $57^{\mathrm{a}}(13)$ & $6^{\mathrm{a}}(1)$ & $7^{\mathrm{b}}(1)$ & $10^{\mathrm{a}}(5)$ & $1083^{\mathrm{a}}(36)$ \\
\hline & 3 & $26^{\mathrm{bc}}(4)$ & $57^{\mathrm{a}}(5)$ & $725^{\mathrm{bc}}(44)$ & $6^{a}(0)$ & $44^{\mathrm{a}}(7)$ & $5^{b}(1)$ & $6^{c}(1)$ & $8^{\mathrm{b}}(3)$ & $889^{\mathrm{b}}(45)$ \\
\hline & 6 & $25^{\mathrm{bc}}(3)$ & $50^{\mathrm{a}}(10)$ & $710^{c}(39)$ & $7^{a}(0)$ & $46^{\mathrm{a}}(25)$ & $4^{c}(0)$ & $8^{a}(1)$ & $10^{\mathrm{a}}(4)$ & $862^{\mathrm{bc}}(41)$ \\
\hline & 9 & $23^{c}(2)$ & $58^{\mathrm{a}}(23)$ & $667^{\text {de }}(40)$ & $7^{a}(0)$ & $40^{\mathrm{a}}(18)$ & $4^{\mathrm{c}}(1)$ & $7^{\mathrm{b}}(1)$ & $9^{\mathrm{b}}(3)$ & $820^{\mathrm{C}}$ \\
\hline & 15 & $19^{\mathrm{d}}(3)$ & $39^{a}(4)$ & $640^{\mathrm{e}}(33)$ & $7^{a}(0)$ & $34^{\mathrm{a}}(17)$ & $3^{d}(1)$ & $5^{c}(0)$ & $7^{c}(2)$ & $755^{\mathrm{d}}(36)$ \\
\hline \% Ret. & & 65 & 60 & 71 & & 60 & 48 & 72 & 70 & 70 \\
\hline
\end{tabular}

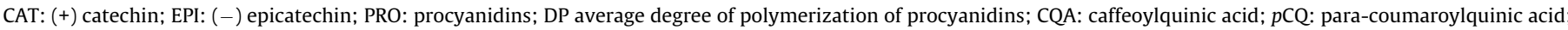
XPL: phloretin xyloglucoside; PLZ: phloridzin; PT: total polyphenols.

\% Ret: percentage of retention. n.d: not detectable.

et al. (2010b). The polyphenol losses could be due to a diffusion mechanism as for sugars. Polyphenols may migrate into the leaching solution. Polyphenol losses might be partially explained by the fracture of the outer layer of cells (cell membranes and cells wall) lost during cutting. However, as calculated for sugar losses, the outer layer of cells represents less than $10 \%$ of apple slice volume. Another mechanism is water massive infiltration, which may increase parenchyma tissues disintegration and cause cytolysis. Lower losses for procyanidins could be linked to the chemical structure, molecular weight or interaction with cell walls. Le Bourvellec et al. (2005) reported that the retention of procyanidins may be due to non-covalent interaction with cell wall components.

\subsubsection{Leaching of polyphenols from thermally treated apple} parenchyma

Phenolic compound concentrations are plotted in Fig. 5 as a function of soaking time. Clear differences were observed between monomeric polyphenols (flavan-3-ol monomers, phenolic acids, and dihydrochalcones, illustrated here by caffeoylquinic acid) and procyanidins. In all cases, most losses occurred during the first $3 \mathrm{~h}$. For procyanidins, losses stayed limited and close to those observed from raw apples; no significant difference was obtained in 'Granny Smith' (Fig. 5c). In 'Golden Delicious' after treatment at $70{ }^{\circ} \mathrm{C}$ (Fig. 5a), the loss increased to approximately $50 \%$, while a trend of increased loss after both $40^{\circ} \mathrm{C}$ and freeze-thaw (reaching approximately 40\% loss after $15 \mathrm{~h}$ in both cases) treatments also emerged. The leaching of monomeric polyphenols increased after treatment at $70^{\circ} \mathrm{C}$ and, in some instances, after freeze-thaw. In ‘Granny Smith' (Fig. 5d), caffeoylquinic acid losses were almost complete after treatment at $70{ }^{\circ} \mathrm{C}$ and freeze-thaw, but they were not significantly different from the raw materials for treatment at $40^{\circ} \mathrm{C}$. In 'Golden Delicious' significantly higher losses were obtained for caffeoylquinic acid after both treatment at $70^{\circ} \mathrm{C}$ (plateau at roughly a $60 \%$ loss) and freeze-thaw (Fig. 5d), still without difference between $40{ }^{\circ} \mathrm{C}$ and raw. As mentioned above, at $70{ }^{\circ} \mathrm{C}$, the cell membranes are expected to lose structural integrity while 
Version définitive du manuscrit publiée dans / Final version of the manuscript published in :

Journal of Food Engineering (2015), Vol. 166, p. 237-246, DOI: 10.1016/j.foodeng.2015.05.037

Journal homepage : http://www.elsevier.com/locatelịfoodeng
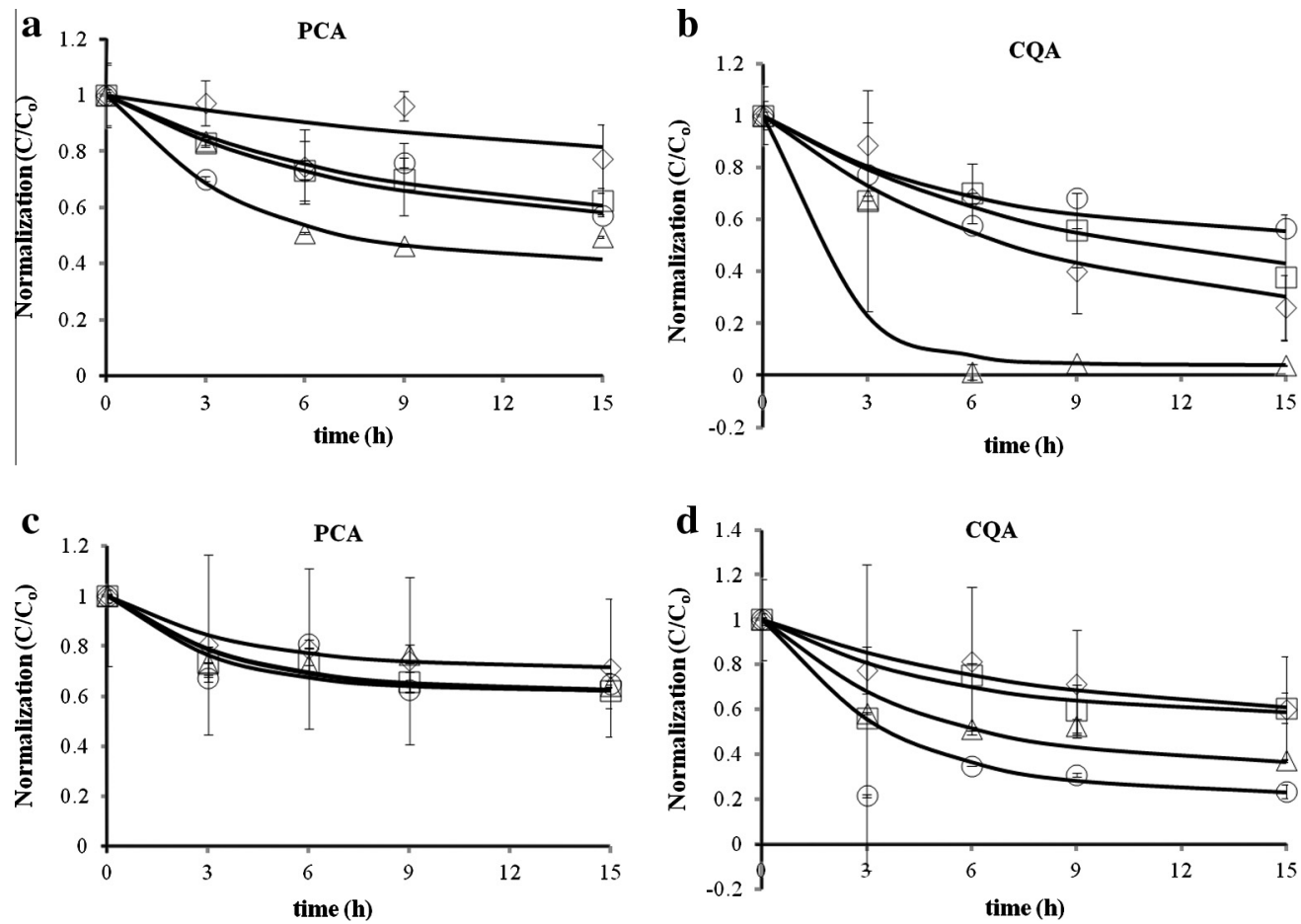

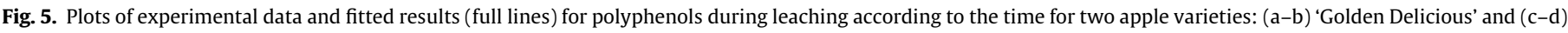
'Granny Smith' (three biological replicates) with raw $(\diamond)$ and treated parenchyma $\left(\square 40{ }^{\circ} \mathrm{C} ; \triangle 70^{\circ} \mathrm{C} ; \bigcirc^{\circ}-25^{\circ} \mathrm{C}\right.$ ). PCA: procyanidins and CQA: caffeoylquinic acid.

Table 3

Estimation of apparent diffusivity constants for the different polyphenols from apple parenchyma (Three Biological Replicates). ${ }^{\mathrm{a}}$

\begin{tabular}{|c|c|c|c|c|c|}
\hline Phenolic compound & Destructuration temperature $\left({ }^{\circ} \mathrm{C}\right)$ & $\mathrm{GD}\left(\times 10^{-9} \mathrm{~m}^{2} \mathrm{~s}^{-1}\right)$ & $C_{\infty} / C_{o}$ & $\mathrm{GS}\left(\times 10^{-9} \mathrm{~m}^{2} \mathrm{~s}^{-1}\right)$ & $C_{\infty} / C_{o}$ \\
\hline CAT & $\begin{array}{r}\text { Raw } \\
40 \\
70 \\
-25\end{array}$ & $\begin{array}{l}0.53 \pm 0.04^{b} \\
0.61 \pm 0.17 \\
\text { n. } \text { d }^{\mathrm{c}} \\
0.67 \pm 0.21\end{array}$ & $\begin{array}{l}0.48 \\
0.50 \\
0.30 \\
0.40\end{array}$ & $\begin{array}{l}0.28 \pm 0.07 \\
0.63 \pm 0.11 \\
0.85 \pm 0.18 \\
1.16 \pm 0.38\end{array}$ & $\begin{array}{l}0.65 \\
0.42 \\
0.42 \\
0.29\end{array}$ \\
\hline EPI & $\begin{array}{r}\text { Raw } \\
40 \\
70 \\
-25\end{array}$ & $\begin{array}{l}0.62 \pm 0.05 \\
0.50 \pm 0.08 \\
1.42 \pm 0.35 \\
0.81 \pm 0.19\end{array}$ & $\begin{array}{l}0.45 \\
0.52 \\
0.30 \\
0.23\end{array}$ & $\begin{array}{l}0.31 \pm 0.11 \\
0.46 \pm 0.12 \\
0.81 \pm 0.17 \\
1.32 \pm 0.30\end{array}$ & $\begin{array}{l}0.60 \\
0.50 \\
0.42 \\
0.27\end{array}$ \\
\hline PRO & $\begin{array}{r}\text { Raw } \\
40 \\
70 \\
-25\end{array}$ & $\begin{array}{l}0.17 \pm 0.12 \\
0.37 \pm 0.06 \\
0.67 \pm 0.21 \\
0.35 \pm 0.14\end{array}$ & $\begin{array}{l}0.77 \\
0.62 \\
0.50 \\
0.23\end{array}$ & $\begin{array}{l}0.24 \pm 0.08 \\
0.36 \pm 0.11 \\
0.29 \pm 0.12 \\
0.32 \pm 0.17\end{array}$ & $\begin{array}{l}0.71 \\
0.62 \\
0.64 \\
0.65\end{array}$ \\
\hline CQA & $\begin{array}{r}\text { Raw } \\
40 \\
70 \\
-25\end{array}$ & $\begin{array}{l}1.00 \pm 0.16 \\
0.69 \pm 0.13 \\
2.99 \pm 1.01 \\
0.44 \pm 0.16\end{array}$ & $\begin{array}{l}0.26 \\
0.38 \\
0.57\end{array}$ & $\begin{array}{l}0.35 \pm 0.08 \\
0.35 \pm 0.24 \\
0.80 \pm 0.24 \\
2.04 \pm 1.01\end{array}$ & $\begin{array}{l}0.70 \\
0.60 \\
0.61 \\
\text { n.d }\end{array}$ \\
\hline pCQ & $\begin{array}{r}\text { Raw } \\
40 \\
70 \\
-25\end{array}$ & $\begin{array}{l}\text { nd } \\
0.38 \pm 0.08 \\
2.87 \pm 1.24 \\
0.48 \pm 0.11\end{array}$ & $\begin{array}{l}\text { n.d } \\
0.61 \\
\text { n.d } \\
0.54\end{array}$ & $\begin{array}{l}\text { n.d } \\
0.34 \pm 0.11 \\
0.59 \pm 0.11 \\
\text { n.d }\end{array}$ & $\begin{array}{l}0.48 \\
0.60 \\
0.60 \\
\text { n.d }\end{array}$ \\
\hline XPL & $\begin{array}{r}\text { Raw } \\
40 \\
70 \\
-25\end{array}$ & $\begin{array}{l}\text { n.d } \\
0.53 \pm 0.04 \\
0.69 \pm 0.09 \\
0.61 \pm 0.12\end{array}$ & $\begin{array}{l}0.60 \\
0.50 \\
0.46 \\
0.46\end{array}$ & $\begin{array}{l}\text { n.d } \\
0.50 \pm 0.17 \\
1.02 \pm 0.26 \\
1.45 \pm 0.54\end{array}$ & $\begin{array}{l}0.72 \\
0.48 \\
0.36 \\
0.28\end{array}$ \\
\hline PLZ & $\begin{array}{r}\text { Raw } \\
40 \\
70 \\
-25\end{array}$ & $\begin{array}{l}\text { n.d } \\
0.08 \pm 0.03 \\
0.46 \pm 0.17 \\
\text { n.d }\end{array}$ & $\begin{array}{l}0.67 \\
0.63 \\
0.29 \\
\text { n.d }\end{array}$ & $\begin{array}{l}0.33 \pm 0.12 \\
0.45 \pm 0.12 \\
0.88 \pm 0.22 \\
0.84 \pm 0.37\end{array}$ & $\begin{array}{l}0.70 \\
0.52 \\
0.37 \\
0.37\end{array}$ \\
\hline PT & $\begin{array}{r}\text { Raw } \\
40 \\
70 \\
-25\end{array}$ & $\begin{array}{l}0.30 \pm 0.10 \\
0.48 \pm 0.15 \\
0.92 \pm 0.25 \\
0.39 \pm 0.14\end{array}$ & $\begin{array}{l}0.66 \\
0.57 \\
0.43 \\
0.54\end{array}$ & $\begin{array}{l}0.26 \pm 0.07 \\
0.38 \pm 0.12 \\
0.37 \pm 0.12 \\
0.40 \pm 0.19\end{array}$ & $\begin{array}{l}0.70 \\
0.60 \\
0.59 \\
0.59\end{array}$ \\
\hline
\end{tabular}

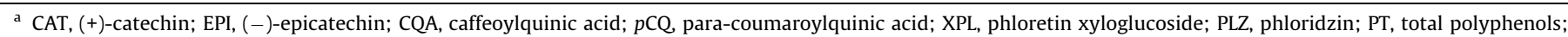
GD, ‘Golden Delicious'; GS, ‘Granny Smith'; $C_{\infty} / C_{o}$, equilibrium polyphenol content.

b Standard error.

c n.d: not determined. 
the cell walls are altered, which should allow easier movement of the various molecules in the tissues, as observed for sugars. As for freeze-thaw, formation of ice crystals leads to the rupture of cell membranes and cell walls, with a marked loss of structure, as observed by Chassagne-Berces et al. (2009), explaining enhanced leaching.

\subsubsection{Estimation of apparent diffusivity constants for polyphenols}

The decrease in polyphenol concentration as a function of time was fitted using Eq. (4) (simplified Crank's solution for Fick's second law applied to a slab) (e.g., Fig. 5 for procyanidins and caffeoylquinic acid). Apparent diffusion coefficients and equilibrium contents are presented in Table 3.

To study the effects of the thermal texture degradation, diffusion was first studied from the raw matrix. The total polyphenol diffusivities for 'Golden Delicious' and 'Granny Smith' were calculated as 0.30 and $0.26 \times 10^{-9} \mathrm{~m}^{2} \mathrm{~s}^{-1}$, respectively. A trend to increase the coefficient of diffusion was first observed in samples treated at $40{ }^{\circ} \mathrm{C}$ and confirmed at $70^{\circ} \mathrm{C}$ and after freeze-thaw (Table 3).

The three treatments (and mostly $70^{\circ} \mathrm{C}$ and freeze-thaw) modified the permeability and destroyed the structural integrity of the principal barriers to diffusive mass transfer of phenolic compounds, namely the tonoplast, plasmalemma lipoprotein and cells walls (Leach et al., 1995).

Diffusivity of monomeric flavan-3-ols and hydroxycinnamic acids increased significantly for both apples after freeze-thaw or treatment at $70^{\circ} \mathrm{C} . D_{e}$ values of monomeric catechins found in 'Granny Smith' were higher than in 'Golden Delicious'. Texture degradation and phenolic compound losses from apple pieces by leaching were linked, probably through the loss of tissue structure, as already described for sugars. However, the two apple varieties presented some differences. As mentioned by Nieto et al. (2007), the independence of some phenolic compound diffusions and apple tissue degradation could be due to non-ideal behaviour of apple tissue during soaking.

In contrast to monomeric polyphenols, diffusivity of procyanidins stayed limited after tissue destructuration, and only a minority of procyanidins leached to water. In 'Granny Smith', procyanidins diffusivity did not seem affected by tissue degradation as the $D_{e}$ value did not change significantly, while, in 'Golden Delicious' leaching increased after $40^{\circ} \mathrm{C}$ and freeze-thaw, and even more after treatment at $70^{\circ} \mathrm{C}$.

\subsection{Histochemical analysis of samples}

\subsubsection{Procyanidin localization by light microscopy}

Microscopic observation of the controls showed parenchymatous cells exhibiting TBO positive granular material in both varieties (Fig. 6A). TBO positive granular material consisted of globular structures occupying the periphery of the vacuoles. Their blue green appearance in the presence of TBO is typical of the procyanidin's nature (O'Brien and McCully, 1981). This is in accordance with the observation of Brillouet and Escoute (2012) thus confirming the advantage of using hemoglobin to stabilize the polyphenolic substances in histochemical approaches.

\subsubsection{Cytohistological effects of thermal treatments}

The effects of the thermal treatment used on cell morphology are summarized in Fig. 6. No noticeable cellular alterations were observed after treatment at $40{ }^{\circ} \mathrm{C}$ in both varieties (Fig. 6B). The parenchymatous cells retained a general morphology similar to that of the raw controls (Fig. 6A). Sections from the $70{ }^{\circ} \mathrm{C}$-treated fruit slices exhibited noticeable structural alterations in the form of cytoplasm shrinkage and cell wall deformation (Fig. 6C). This decrease in cell volume indicates a loss of cell and vacuole contents, likely due to a rupture of physiological and mechanical barriers.
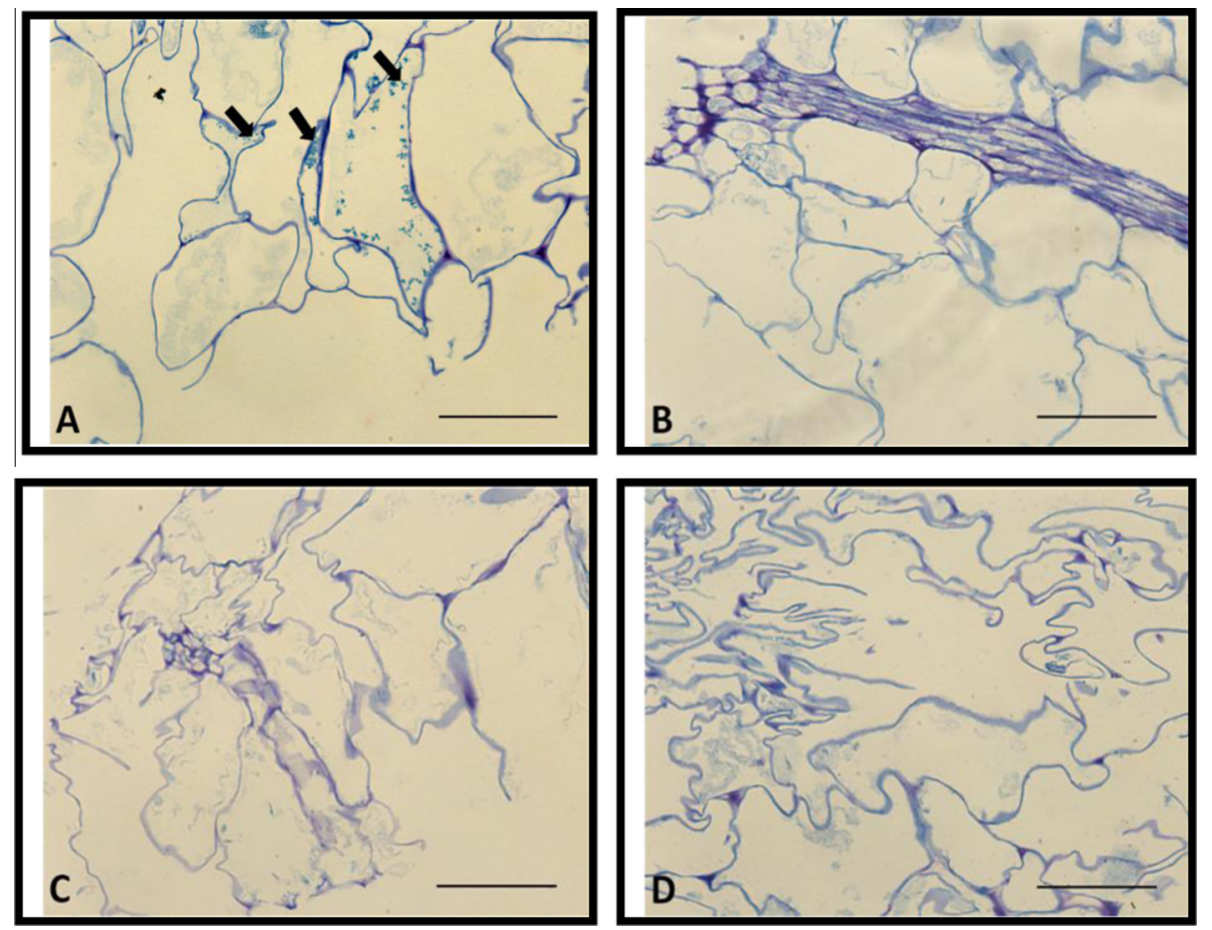

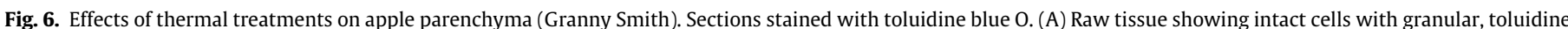

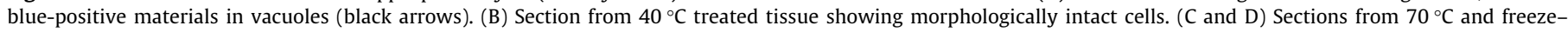
thawed treated tissues, respectively showing shrinkage and destructuration. All scales bars $=100 \mu \mathrm{m}$. 

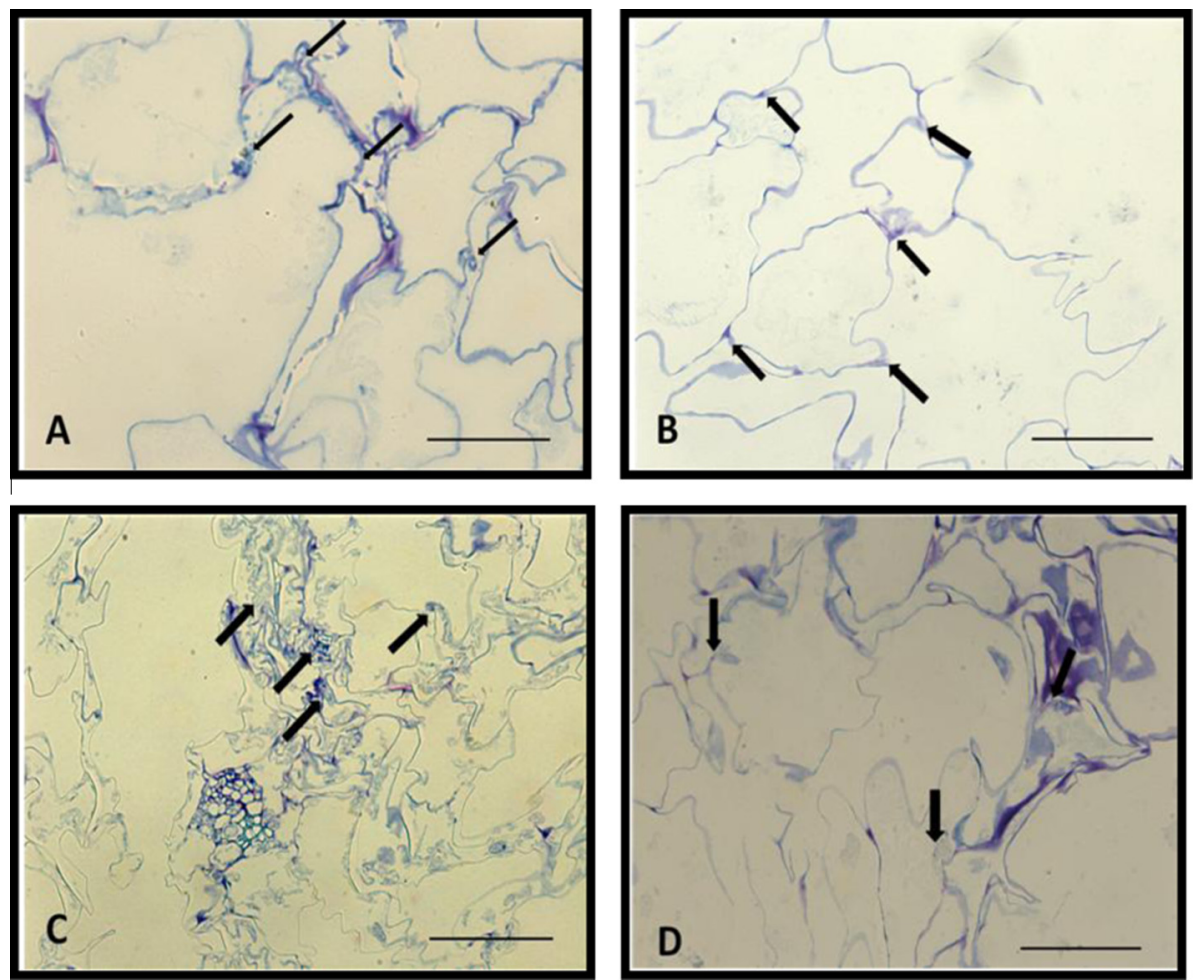

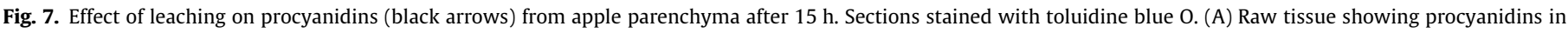

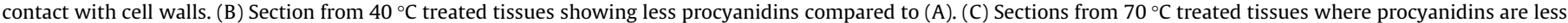
abundant. (D) Section from freeze-thawed tissues showing an important reduction in the procyanidin content of cells. All scales bars $=100 \mu \mathrm{m}$.

Sections from $-25{ }^{\circ} \mathrm{C}$-treated samples showed a profound cytomorphological alteration of the parenchymatous cells of both varieties (Fig. 6D). The cells were completely destructured with collapsed vacuoles and disintegrated cell walls. Chassagne-Berces et al. (2009) reported similar changes in freeze-thawed apple tissues. It is well known that freezing (production of ice crystals) induces cell destructuration, resulting in the loss of the regular cell wall shape (Chassagne-Berces et al., 2009).

3.5.3. Effects of parenchyma destructuration on procyanidin leaching

Fig. 7 presents sections of apple parenchyma after soaking. The fates of cellular procyanidins varied per treatment. Samples subjected to $40^{\circ} \mathrm{C}$ treatment for $30 \mathrm{~min}$ showed procyanidins located in vacuoles, as in the controls for both varieties (Fig. 7B). However, sections from the samples heated at $70{ }^{\circ} \mathrm{C}$ for 30 min or frozen at $-25^{\circ} \mathrm{C}$ for $60 \mathrm{~min}$ displayed less procyanidin globules, which have come in contact with cell walls (Fig. 7C and D).

Cytohistological observations are in accordance with the biochemical analysis. A decreased level and relocalization of procyanidins on cell walls after the leaching process were observed for raw and treated tissues.

Relocalization of most of the tannins present on cell walls could be due to non-covalent interactions with cell wall materials, as proposed by Renard (2005) and Le Bourvellec et al. (2011). Fig. 7C and D shows the probable interaction of procyanidins with cell walls materials. Biochemical analysis performed by Le Bourvellec et al. (2005) have demonstrated this type of interaction.

\section{Conclusion}

Experimental methodologies and estimation of solute diffusivities based on Fick's second law could be applied to polyphenol migration in apple slices as evidenced by their leaching, though model fit was not always very high. Cell degradation (by treatment at $70{ }^{\circ} \mathrm{C}$ or $-25^{\circ} \mathrm{C}$ ) increased polyphenol diffusion. Values of their apparent diffusivity constants increased after treatment, while residual concentrations decreased. Apple parenchyma after thermal (heat or freeze-thaw) processing showed extensive microstructural changes. These changes affected the solid-liquid extraction of macroconstituents (sugars) and microconstituents (polyphenols) as measured by their ability to diffuse out of the matrix during the extraction process. The different cell destructuring treatments had slightly different impacts. A different behaviour was observed for procyanidins, for which histological and biochemical results concur to indicate retention by cell walls.

\section{Acknowledgments}

We would like to especially thank the Research and Study Ministry of Cote d'Ivoire for providing Ph.D Grant for Mouhamadou Kebe. This research was supported by the European Community's Seventh Framework Program (FP7/2007-2013) under Grant Agreement FP7-222-654 DREAM. We are grateful to the SQPOV Fruit Team for their assistance and for their technical expertise.

\section{Appendix A. Supplementary material}

Supplementary data associated with this article can be found, in the online version, at http://dx.doi.org/10.1016/j.jfoodeng.2015.05. 037.

\section{References}

Ader, P., Grenacher, B., Langguth, P., Scharrer, E., Wolffram, S., 1996. Cinnamate uptake by rat small intestine: transport kinetics and transepithelial transfer. Exp. Physiol. 81, 943-955. 
Benhamou, A., Idlimam, A., Lamharrar, A., Benyoucef, B., Kouhila, M., 2008. Diffusivité hydrique et cinétique de séchage solaire en convection forcée des feuilles de marjolaine. Revue des Energies Renouvelables 11, 75-85.

Bernards, M.A., Lewis, N.G., 1998. The macromolecular aromatic domain in suberized tissue: a changing paradigm. Phytochemistry 47, 915-933.

Billy, L., Mehinagic, E., Renard, C.M.G.C., Prost, C., 2008. Relationship between texture and pectin composition of two apple cultivars during storage. Postharvest Biol. Technol. 47, 315-324. http://dx.doi.org/10.1016/ j.postharvbio.2007.07.011.

Bourles, E., Mehinagic, E., Courthaudon, J.L., Jourjon, F., 2009. Impact of vacuum cooking process on the texture degradation of selected apple cultivars. J. Food Sci. 74 (9), 512-518.

Boyer, J., Liu, R.H., 2004. Apple phytochemicals and their health benefits. Nutr. J. 3 (5), 1-15.

Brillouet, J.-M., Escoute, J., 2012. A new technique for visualizing proanthocyanidins by light microscopy. Biotech. Histochem. 87 (3), 195-200.

Bureau, S., Scibisz, I., Le Bourvellec, C., Renard, C.M.G.C., 2012. Effect of sample preparation on the measurement of sugars, organic acids, and polyphenols in apple fruit by mid-infrared spectroscopy. J. Agric. Food Chem. 60, 3551-3563.

Cadot, Y., Chevalier, M., Barbeau, G., 2011. Evolution of the localisation and composition of phenolics in grape skin between veraison and maturity in relation to water availability and some climatic conditions. J. Sci. Food Agric. 91 (11), 1963-1976.

Campeanu, G., Neata, G., Darjansch, G., 2009. Chemical composition of the fruits of several apple cultivars growth as biological crop. Notulae Botanicae Horti Agrobotanici Cluj-Napoca 2, 161-164.

Chassagne-Berces, S., Poirier, C., Devaux, M.-F., Fonseca, F., Lahaye, M., Pigorini, G., Girault, C., et al., 2009. Changes in texture, cellular structure and cell wall composition in apple tissue as a result of freezing. Food Res. Int. 42 (7), 788797.

Crank, J., 1975. The Mathematics of Diffusion, second ed. Clarendon Press, Oxford. De Belie, N., 2002. Use of physico-chemical methods for assessment of sensory changes in carrot texture and sweetness during cooking. J. Texture Stud. 33, 367-388.

Delchier, N., Reich, M., Renard, C.M.G.C., 2012. Impact of cooking methods on folates, ascorbic acid and lutein in green beans (Phaseolus vulgaris) and spinach (Spinacea oleracea). LWT - Food Sci. Technol. 49 (1), 197-201.

Devic, E., Guyot, S., Daudin, J.-D., Bonazzi, C., 2010a. Kinetics of polyphenol losses during soaking and drying of cider apples. Food Bioprocess Technol. 3, 867-877.

Devic, E., Guyot, S., Daudin, J.-D., Bonazzi, C., 2010b. Effect of temperature and cultivar on polyphenol retention and mass transfer during osmotic dehydrated of apples. J. Agric. Food Chem. 58, 606-614.

Fujita, S., Tono, T., 1988. Purification and some properties of polyphenoloxidase in eggplant (Solanum melongena). J. Sci. Food Agric. 46 (1), 115-123.

Greve, C., Shackel, K., Ahmadi, H., McArdle, R., Gohlke, Labavitch, J., 1994. Impact of heating on carrot firmness: contribution of cellular turgor. J. Agric. Food Chem. 42, 2896-2899.

Guyot, Marnet., Drilleau, J., 2002. Procyanidins are the most abundant polyphenols in dessert apples at maturity. Lebensmittel - Wissenschaft und technologie 51, 6240-6247.

Guyot, S., Marnet, N., Laraba, D., Sanoner, P., Drilleau, J.-F., 1998. Reversed-phase HPLC following thiolyse for quantitative estimation and characterization of the four main classes of phenolic compounds in different tissue zones of a French cider apple variety (Malus Domestica Var. kermerrien). J. Agric. Food Chem. 46, $1698-1705$.

Jemai, A.B., Vorobiev, E., 2002. Effect of moderate electric field pulses on the diffusion coefficient of soluble substances from apple slices. Int. J. Food Sci. Technol. 37, 73-86.

Kebe, M., Renard, C.M.G.C., Amani, G.N.G., Maingonnat, J.-F., 2014. Kinetic of apple polyphenol diffusion in solutions with different osmotic strength. J. Agric. Food Chem. 62, 9841-9847.
Keurentjes, J.T.F., Janssen, A.E.M., Broek, A.P., Van der Padt, A., Wesselingh, J.A., Van T'Riet, K., 1992. Multicomponent diffusion in dialysis membranes. Chem. Eng. Sci. 47, 1963-1971

Klewicki, R., Uczciwek, M., 2008. Effect of osmotic dehydration in fructose, sucrose and fructooligosaccharide solutions on the content of saccharides in plums and apples and their energy value. Agric. Food Sci. 17 (4), 367-375.

Le Bourvellec, C., Bouchet, B., Renard, M.G.C., 2005. Non-covalent interaction between procyanidins and apple cell wall material. Part III: Study on model polysaccharides. Biochim. Biophys. Acta 1725, 10-18.

Le Bourvellec, C., Bouzerzour, K., Ginies, C., Regis, S., Plé, Y., Renard, C.M.G., 2011 Phenolic and fiber composition of applesauce is close to that of apple flesh. J. Food Compos. Anal. 24, 537-547.

Leach, G., Pyle, L., Niranjan, K., 1995. Effective diffusivity of total solids and pectic substances from apple tissue. Int. J. Food Sci. Technol. 29, 687-697.

Lin, T.-T., Pitt, R.E., 1986. Rheology of apple and potato tissue as affected by cell turgor pressure. J. Texture Stud. 17, 291-313.

Macheix, J.-J., Fleuriet, A., Sarni-Manchado, P., 2003. Composés phénoliques dans la plante-Structure, biosynthèse, répartition et rôles. In: Sarni-Manchado, P. Cheynier, V. (Eds.), Les polyphénols en agroalimentaire. Lavoisier, Paris.

Mehinagic, E., Bertrand, D., Symoneaux, R., 2003. Relationship between sensory analysis, penetrometry and visible NIR spectroscopy of apples belonging to different cultivars, vol. 14, pp. 473-484. doi:10.1016/S0950-3293(03)00012-0.

Nieto, A.B., Castro, M.A., Salvatori, D., Alzamora, S.M., 2007. Viscoelastic characteristics of Granny Smith apple during glucose osmotic dehydration. J. Food Eng. 83, 394-403.

O'Brien, T.P., McCully, M., 1981. The study of plant structure: principles and selected methods. Anat. Morphol. 357.

Oszmianski, J., Wolniak, M., Wojdylo, A., Wawer, I., 2007. Comparative study of polyphenolic content and antiradical activity of cloudy and clear apple juices. J. Food Agric. 579 (December 2005), 573-579.

Renard, C.M.G.C., 2005. Effects of conventional boiling on the polyphenols and cell walls of pears. J. Sci. Food Agric. 318 (October 2004), 310-318.

Rice, P., Selman, J.D., Abdul-Rezzak, R.K., 1990. Nutrient loss in the hot water blanching of potatoes. Int. J. Food Sci. Technol. 25, 61-65.

Sanoner, P., Guyot, S., Marnet, N., Molle, D., Drilleau, J.-F., 1999. Polyphenol profiles of french cider apple varieties (Malus Domestica sp.). J. Agric. Food Chem. 47 (12), 4847-4853.

Scharwtzberg, H., Chao, R., 1982. Solute diffusivities in leaching processes. Food Technol. 36, 73-86.

Sineiro, J., Domfnguez, H., Ntifiez, M.J., Lema, J.M., 1996. Ethanol extraction of polyphenols in an immersion extractor. Effect of pulsing flow. J. Am. Oil Chem. Soc. 73 (9), 1121-1125.

Valavanidis, A., Vlachogianni, T., Psomas, A., Zovoili, A., Siatis, V., 2009. Original article polyphenolic profile and antioxidant activity of five apple cultivars grown under organic and conventional agricultural practices. Int. J. Food Sci. Technol., 1167-1175

Van Buggenhout, S., Silan, D.N., Duvetter, T., Van Loey, A., Hendrickx, M., 2009. Pectins in processed fruits and vegetables: Part III texture engineering. Compreh. Rev. Food Sci. Food Saf. 8, 105-117.

Varzakas, T.H., Leach, G.C., Israilides, C.J., 2005. Theoretical and experimental approaches towards the determination of solute effective diffusivities in foods. Enzym. Microbial Technol. 37, 29-41.

Vrhovsek, U., Rigo, A., Tonon, D., Mattivi, F., 2004. Quantitation of polyphenols in different apple varieties. J. Agric. Food Chem. 52, 6532-6538.

Waldron, K.W., Smith, A.C., Parr, A.J., Ng, A., Parker, M.L., 1997. New approaches to understanding and controlling cell separation in Relation to fruit and vegetable texture. Trends Food Sci. Technol. 8, 213-218.

Wu, X., Beecher, G.R., Holden, J.M., Haytowitz, D.B., Gebhardt, Prior, R.L., 2004 Lipophilic and hydrophilic antioxidant capacities of common foods in the United States. J. Agric. Food Chem., 4026-4037 